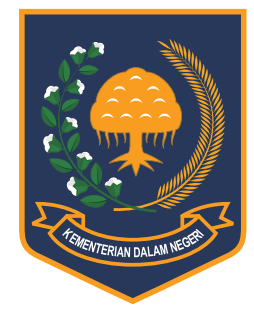

Jurnal Bina Praja 8 (2) (2016): 293-304

Jurnal Bina Praja

e-ISSN: 2503-3360 | p-ISSN: 2085-4323

Accreditation Number

735/AU2/P2MI-LIPI/04/2016

http://jurnal.kemendagri.go.id/index.php/jbp/index

\title{
THE LOCAL INITIATOR ROLE IN THE ADOPTION OF BIOGAS ENERGY INNOVATION FOR HOUSEHOLD NEEDS IN RURAL AREAS
}

\author{
Hartiningsih ${ }^{1, *}$ \\ ${ }^{1}$ Science and Technology Development Research Centre (PAPPIPTEK) \\ Indonesian Institute of Sciences (LIPI) \\ Gedung A PDII LIPI, Lantai 4 Jl. Jend. Gatot Subroto No. 10 Jakarta 12710
}

Received: 23 June 2016; Accepted: 2016; Published online: 30 November 2016

DOI: $10.21787 / \mathrm{jbp} .08 .2016 .293-304$

\begin{abstract}
The need for Kerosene is very high. When energy crisis hit Indonesia, it caused the scarcity and soaring prices of kerosene. Hence, finding alternative energy sources is needed, especially a renewable energy to households. One is which is Biogas energy. Biogas is an energy that uses simple technology, which uses raw materials of animal waste. Many rural communities do not know about it, so it requires a pioneer, called the local initiator. The local initiator is an agent of change that comes from the local community, who has the initiative to make changes and become a guide passage of the change process in an organization or community, in order to achieve the expected goals. Local initiator becomes an important factor in the success of biogas innovation adoption. Biogas is used for household needs such as cooking, water heating, and lighting. Biogas program has been reinforced by Presidential Decree No 5 of 2006, Minister of ESDM Regulation (Permen ESDM) No 3 of 2013, Permen ESDM No 10 of 2015, and Minister of Rural Affairs Regulation (Permen Desa) No 5 of 2015. This paper aims to examine the role of a local initiator as an agent of change and the most dominant factors in the successful adoption of biogas for the needs of rural households. This study uses a qualitative method by using a case study approach and conducting a descriptive analysis. The focus of the data analysis is only performed on the local initiator in the successful adoption of biogas in Haurngombong village in West Java and Pandua-North Lombok, NTB. The result of the study shows that the successful adoption of biogas in Haurngombong Village and Pandua Village is strongly influenced by the local initiator. The local initiator success is not determined by the position, age, and gender, but is determined by the experience in the use of biogas, biogas sector knowledge, dissemination strategies, and communication among stakeholders of biogas program. The key to the success of local initiators in the adoption of biogas innovation lies in good communication with the public.
\end{abstract}

Keywords: local initiator, adoptions, innovation, biogas, EBT.

\section{INTRODUCTION}

Since the kerosene crisis happened in Indonesia, it became increasingly difficult for the people to get the kerosene despite it is the most widely used fuel by the people for everyday purposes. Even in some provinces, the scarcity of kerosene often happens and the selling price of kerosene by the people is getting higher. To overcome the scarcity, in 2007 the government made a diversion program of subsidy and the use of kerosene by the people to $3 \mathrm{~kg} \mathrm{LPG}$ gas through the distribution of $3 \mathrm{~kg} \mathrm{LPG}$ package along with its content, stove, regulator, and hose for free to the public. In fact, the price of LPG is still considered too expensive and it is hard to come by in the rural areas. While in Indonesia, actually it has other substitute materials that are very abundant in number, called biogas. For this reason, people especially in rural areas, which used to use kerosene stoves began to switch to biogas energy that is cheap and easy. To obtain biogas energy, needed to build a biogas plant commonly called biodigester or digester. The advantage of the biogas energy source is it is renewable so that it can provide a source of sustainable energy. The technology to produce biogas is simple, through

\footnotetext{
* Corresponding Author

Phone : +62 215225711 ext. 4037

Email : hartningsih25@gmail.com
} 
the process of fermentation. The usefulness of this energy can meet household needs such as cooking, water heating, lighting (petromax lamp), and even for a refrigerator.

This program has been strengthened by the Presidential Regulation No 5 of 2006 on The National Energy Policy to overcome the scarcity of energy by the use of new and renewable energy (EBT). In addition, the government also provided support in the use of alternative energy by allocating a portion of the reduction in fuel subsidies to develop biogas from livestock waste to all areas in the countryside. Special Allocation Fund (DAK) on Rural Energy Sector, which is a fund from the State Budget (APBN). In the Minister of Energy and Mineral Resources Regulation (Permen ESDM) No 3 of 2013, that since the fiscal year of 2013, the DAK of the Ministry of Finance will facilitate the utilization of biogas. This program is supported by the government with the Regulation of the Minister of Energy and Mineral Resources No 10 of 2015 on Technical Guidelines for the Use of Special Allocation Fund for Rural Energy Sector in the fiscal year of 2015. Article 1 paragraph 6 stated that DAK is allocated to help fund the activities, one of which is biogas. There is also the Ministry of Village Regulation No 5 of 2015 on The Priority Settlement on the Village Fund Use in 2015. In principle, the village fund amounting to IDR283.77 million per village can be used for the development of renewable energy (chapter 8) and the development and management of selfsufficient energy (Article 9). For the success of the development program, required an initiation from the local governments to develop biogas that has been done by the government, non-government organizations, and in particular, the community itself to be continued and enhanced.

In Indonesia, the biogas has a great opportunity in its development, but in reality, cannot be socialized/fused just in the rural communities. Because there are several factors from inside and outside the community that affect the adoption of this innovation. From the results of the study in 2011, that the adoption of biogas, like in West Java, is less significant, with reasons as follows 1) people still prefer to use gas than biogas because the gas price is still affordable and accessible; 2) The land belongs to the community is very narrow that it cannot be used for the digester; 3 ) the existence of the debt in the cooperative so it cannot add debt to pay the cost of the digester; 4) The apathy nature of the people who have used perishable plastic biogas reactor (Hermawati, Wati, et al., 2011). And, the study result from the Indonesian Institute for Breeder Development (Martaleo, M, 2014) stated that in Subang area, there are 194 cattle ranchers and only about 95 that use biodigester, because the cost of purchasing biodigester is expensive and lack of understanding of biogas because of poor education.

From the above study result, in order for the biogas energy to be developed in rural communities, it takes someone to be a pioneer, which may be called a local initiator, who act as the local change agent, who becomes the guide in the process of passage of changes that occur in an organization, as well as in a society in order to achieve the desired goals. The local initiator should be able to introduce new ideas, which can be said as the innovation in that area. According to Roger (2003), the local initiator is an individual or a person who has a duty to influence the change target or goal so that the innovation adoption is successful as expected. In addition, the local initiator also becomes a link between the innovation and the society system that becomes the change target. For that reason, required a strategy for achieving the adoption of innovation in the social system in a society called communication. According to Rogers, 1995 (in Hartiningsih, 2015), that communication is a tool to convey messages of innovation from the source to the recipient. The key to the successful adoption of innovation lies in good communication between the local initiator and the community. If the communication is smooth and effective, then technology adoption will be faster and closer to the achievement of the desired objectives. Hence the importance of the local initiator role.

This paper aims to examine the role of local initiator in its role as an agent of change that determines the success of innovation adoption of biogas energy to the needs of rural households.

The result of the previous studies using descriptive statistical approach stated that an agent of change in the management of change is not specified by their gender, age, formal education, and the length of working in education (Harsiwi, 2003). From the research by Rahmadhani, N. (2011) that the agent of change in the field is not limited as an assistant but also as a motivator like a member who wants to make changes. Besides, a change agent needs to provide a clear example to the community. With the real example, it is expected that there will be a social change in society, but in fact, changing the people's habits is not easy, it takes a long and sustained effort (Waluyo and Ari Nurlia, 2013). In addition, the role of an agent of change is very important in life and improve people's lives to achieve real improvement of social welfare, although there are many constraints, such as low levels of education and high unemployment rates (Sukmawati, 2013). Muflikhati's study (2011) showed that the adoption of biogas is not easy even if it is profitable for society because they want the energy that is easily obtainable. 


\section{MeThOD}

This paper is based on a research that has been done with the fund of PAPPIPTEK LIPI in 2011 to 2014 with regards to renewable energy, especially in Haurngombong Village in West Java and Pandua Lantan Village, NTB where biogas energy program has been implemented as a program to provide energy and improve the quality of people's lives.

The author uses a qualitative method by using a case study approach. This study is conducted to focus on a social change made by the local initiator in biogas technology adoption. According to Sugiyono (2014), that qualitative research is a research in which the data is more on the interpretation of the data found in the field. Moreover, qualitative research is used to examine the condition of natural objects, data analysis is inductive, and a qualitative research emphasizes more on the significance rather than the generalization (Pope and Mays, 1995 in Simatupang, 2016).

The subjects in the study that has been conducted are the people who are involved in the spreading activity of biogas and the community that use biogas in Haurngombong Village and Pandua Village. The data used is secondary data and primary data. The secondary data is sourced from literature, newspapers, the internet, and previous research report. And, primary data obtained directly from the informant. The primary data obtained through interviews. The interviews are conducted in the form of semi-structured interviews with in-depth questions, with the use of notes and tape recorders.

The data collected will be analyzed using the qualitative descriptive analysis, which is an analysis by describing and reviewing existing data from both primary data and secondary data (Sugiyono, 2014).

\section{RESULT AND DISCUSSION}

This discussion will be described in four sections, namely theoretical framework, the adoption of technology phase, the role of actor, and the success of local initiators in influencing the community.

\section{A. Theoretical Framework}

\section{1) Innovation Adoption}

A local Initiative is an agent of change that comes from the local community, who has the initiative to make changes and become guides to the process of passage of the changes that occur in an organization and in a community, in order to achieve the expected goals. In addition, a local initiator is a link between innovation applied and the community that becomes the target of change. The local initiator is needed because of the difficulty in communicating directly the innovation with the client in order to achieve the adoption of innovation in the social system in society.

Communication is the process of sharing information between the society social system that created a finding (innovator) with the target of change (society group) or is the process of sharing information among themselves so that the adoption of these innovations can be managed effectively. The local Initiator's role is very important in the successful adoption of innovation. For that, the local initiators should also be the socialization agent to be able to attract people around him to use such innovation.

A local initiator may be regarded as an agent of change if he can understand what innovations to offer to others, the goal is clear, and has a plan of change to be made in the community, and even able to be a Role Model or the first to carry out such changes or Early Adopter (Roger, 1962; Ishelina and Hartiningsih, 2014). In Ristanurita (2013), a person can be regarded as an agent of change if he has a role in that change, i.e. as 1) catalyst, 2) solution giver or provider of solutions, 3) process helper, and 4) resources linkers or resource connector.

\section{2) Local Initiator}

Adoption of innovation is a part of the stages in the innovation reception by the user, or the process in a person when first started hearing about an innovation to accept or reject the innovation (Roger, 1995; Hartiningsih, 2013). The adoption of innovation can work well depending on the innovation diffusion process or dissemination conducted.

In the decision-making process for innovation, Rogers and Shoemaker (in Soekarwi, 1988; Ishelina, 2014) indicates that there are some important elements that need to be considered, including the mental attitude to innovation adoption, and the confirmation of the decisions taken. The phases of the decision-making process of innovation adoption (Roger, 1995; Hartiningsih et al., 2013; Ishelina et al., 2014), are (1) Emergence of Knowledge Phase, (2) Persuasion Phase, (3) Decisions Phase, (4) Implementation Phase, (5) Confirmation Phase.

The successful adoption of innovation to the community is dependent on how the role of the local initiator as the agent of change and how to socialize in order to be able to attract people around him to use such technology. According to Roger, there are eight factors that affect local initiator in influencing society (Rogers E.M., 1962; Ishelina and Hartiningsih, 2014), namely (1) The effort of the agent of change himself and the amount of time used; (2) Orientation and expectation of clients towards the adoption of innovation; (3) Innovation suitability with client needs; (4) Empathy of the agent of change to the client and vice versa from 
the client to the agent of change; (5) Interaction between the agent of change with the client; (6) The credibility of the agent of change that leads to trust and does not arise suspicion of the client; (7) In line with the opinion leader, the agent of change should focus more on communication with the opinion leader, and (8) the ability of client evaluation.

\section{3) Development and Local Government}

The development activity is carried out fully to create people's better lives. Development can be briefly defined as a planned activity that is carried out in order to get the change for the better. According to Rogers and Shoemaker (1971), which says that development is a type of social change, in which there are new ideas being introduced in a social system that aims to generate income and a better life. Development in the region cannot be separated from the role of a local government because the government is the implementer of government affairs in accordance with Law no. 32 in 2004. The local government has huge authority for planning, formulating, implementing, and evaluating the development policies and programs that fit the needs of local communities (Agustino, Leo, 2008). According to Josep Riwu Kaho (1996), one of the local government authorities is to have a certain affair that is a matter submitted by the central government. Therefore, the local government should implement the Minister of ESDM Regulation No 10 of 2015 and the Minister of Village Regulation No 5 of 2015 to develop biogas and renewable energy in the region.

\section{4) Biogas Energy for Household Needs}

Biogas energy is the energy generated from animal waste, for example, waste from cow, buffalo, horses, and pigs (Hermawati, Wati, et al., 2011). Household-scale biogas can deliver sustainable solutions for every household that has cattle to reduce dependence on firewood and kerosene that are increasingly expensive and scarce. According to Musanif (2009) and Ishelina \& Hartiningsih (2014) that biogas can be used as the substitute for fuels, such as LPG, kerosene, and firewood. In other words, biogas is an established type of renewable energy technology (proven technology), especially to be implemented on a household scale in rural communities.

Biogas technology is a technology that is very simple, requiring only the construction of the biogas reactor or called biodigester or digester. This biogas digester can turn livestock waste into biogas that replaces the use of kerosene and LPG for cooking, heating, and lighting. The fire generated by the livestock waste is odorless and blue, does not leave a mark on cookware. The digester can fulfill the energy needs of households, in which a household must have at least two cows that are stabled or provide a minimum of $40 \mathrm{~kg}$ of cow dung. Another benefit is that biogas dregs left over from this process (slurry) can be an excellent organic fertilizer to increase the result and quality of crops.

\section{B. Technology Adoption Phase}

The technology adoption by Roger (2003) is viewed from two stages, the first is the initiation stage or an early adoption of innovation, comprising the emergence of Knowledge phase: to understand the existence and advantages/benefits and how an innovation functions, the Persuasion phase: to measure the benefits that will be able to adopt such innovations personally, and decision phase: activity that leads to the selection of the adoption or rejection of an innovation, and the second one is the implementation phase, which consists of the implementation phase: the unit of other decisionmakers specify the use of an innovation, and the Confirmation phase: units of other decision-makers seeking to strengthen the decision of acceptance or rejection of innovations that have been made previously.

\section{1) Haurngombong Village-West Java}

Haurngombong Village is a village in which the majority of the community is farmers and dairy farmers. This causes many cow wastes to be an environmental issue and the cause of disease because of a large number of flies. Therefore, this village develops the use of biogas from cow waste that can be used for household purposes such as cooking and house lighting. The phase can be seen in Figure 1.

At the initiation/early phase of adoption in Haurngombong village, Mr. A as the Village Head sees a lot of cow dungs cause a dirty environment, a lot of flies and consequently many people are sick. In 2002, Mr. A met an ITB lecturer who was conducting a research on biogas and provided insight on biogas, and that was the first time it was communicated and then introduced the knowledge about biogas. Finally, $\mathrm{Mr}$. A made a digester from plastics, at the time the price was IDR300.000.00 and biogas can be used to cook in the family A. At the following phase, which is a persuasion phase where Mr. A communicates to the public with the help of young people in the village, but the people refused, although the technology is not contrary to the values, customs, and beliefs in the village. The primary reason to reject is because a biogas digester is expensive due to the cost of making and the kerosene used as raw material for cooking and lighting for households was still easy to look for with a cheap price.

In 2007, when happened an increase in fuel prices (Raw Oil Material), so that the price of kerosene soared and it was difficult to find. People 


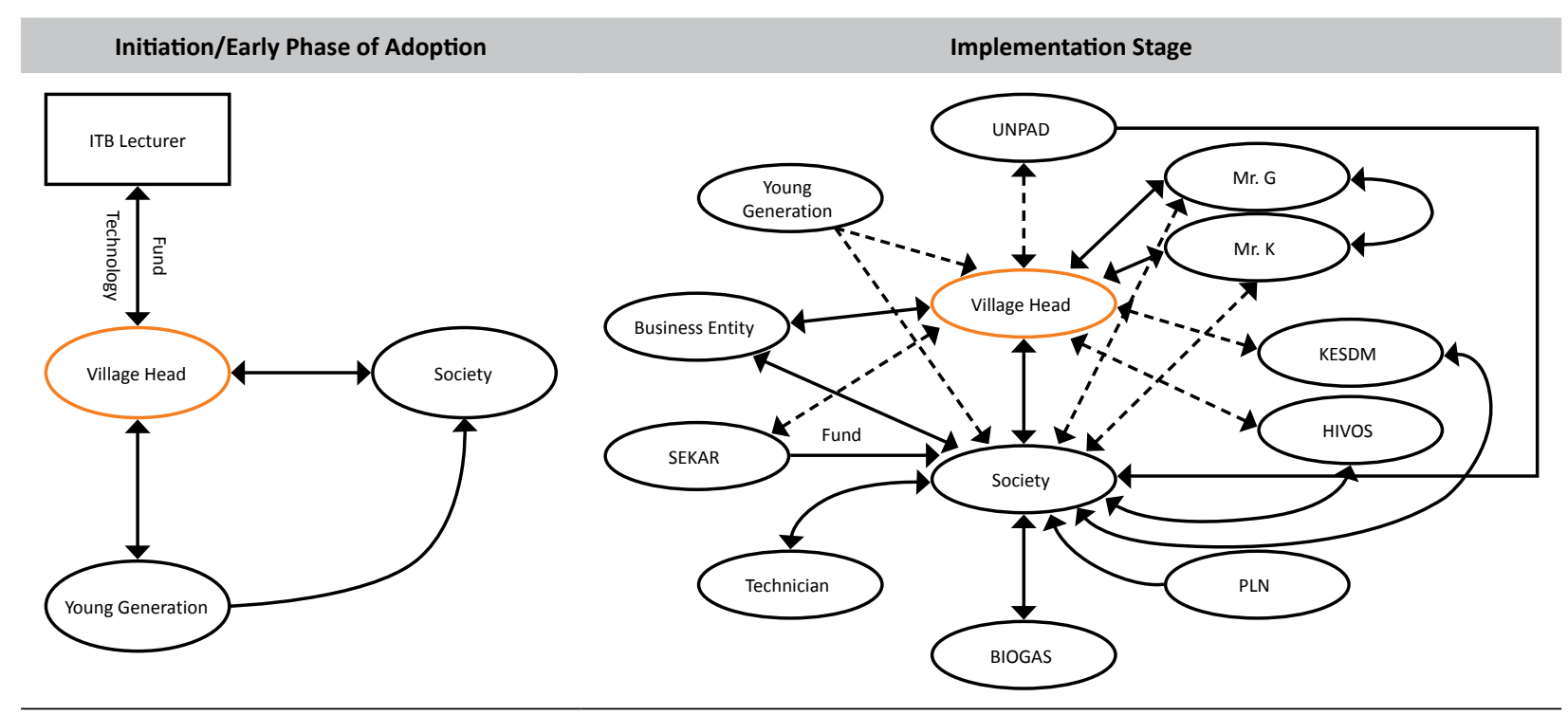

Figure 1. The Technology Adoption Phase in Haurngombong Village

were starting to get confused and saw that Mr. A's family was not affected by the rise and scarcity of kerosene, then the community finally decided to (willing to) adopt the biogas as the one used by Mr. A.

The second phase, which is the implementation phase. In 2007, as many as 60 families made digesters at their private expense. The use of biogas is intensified through a cooperation with the Faculty of Animal Husbandry of Padjadjaran University (UNPAD), Bandung. In 2008, established the VillageOwned Enterprise to manage funds from SEKAR (Worker Union of PT Telkom). The fund was used to assist the people in making digesters. With the socialization of the village heads and community leaders as well as the younger generation, as well as the communication between people who already used the other thing, then the number of digesters increased to 270 units in 2008, and in 2012, it amounted to 300 units from 300 breeders, which means $100 \%$ of the farmers already used biogas.

\section{2) Pandua Lantan Village-North Lombok NTB}

The innovation adoption phase in Pandua Lantan Village can be illustrated in Figure 2.

At the initiation/early phase of the innovation adoption, originated from Mr. AW who is a former migrant worker from Korea, who already have the knowledge and have been using the biogas while being a migrant worker. After returning to his village, seeing a lot of heaping cow waste, resulting in smelly odor, and a lot of flies in the vicinity that

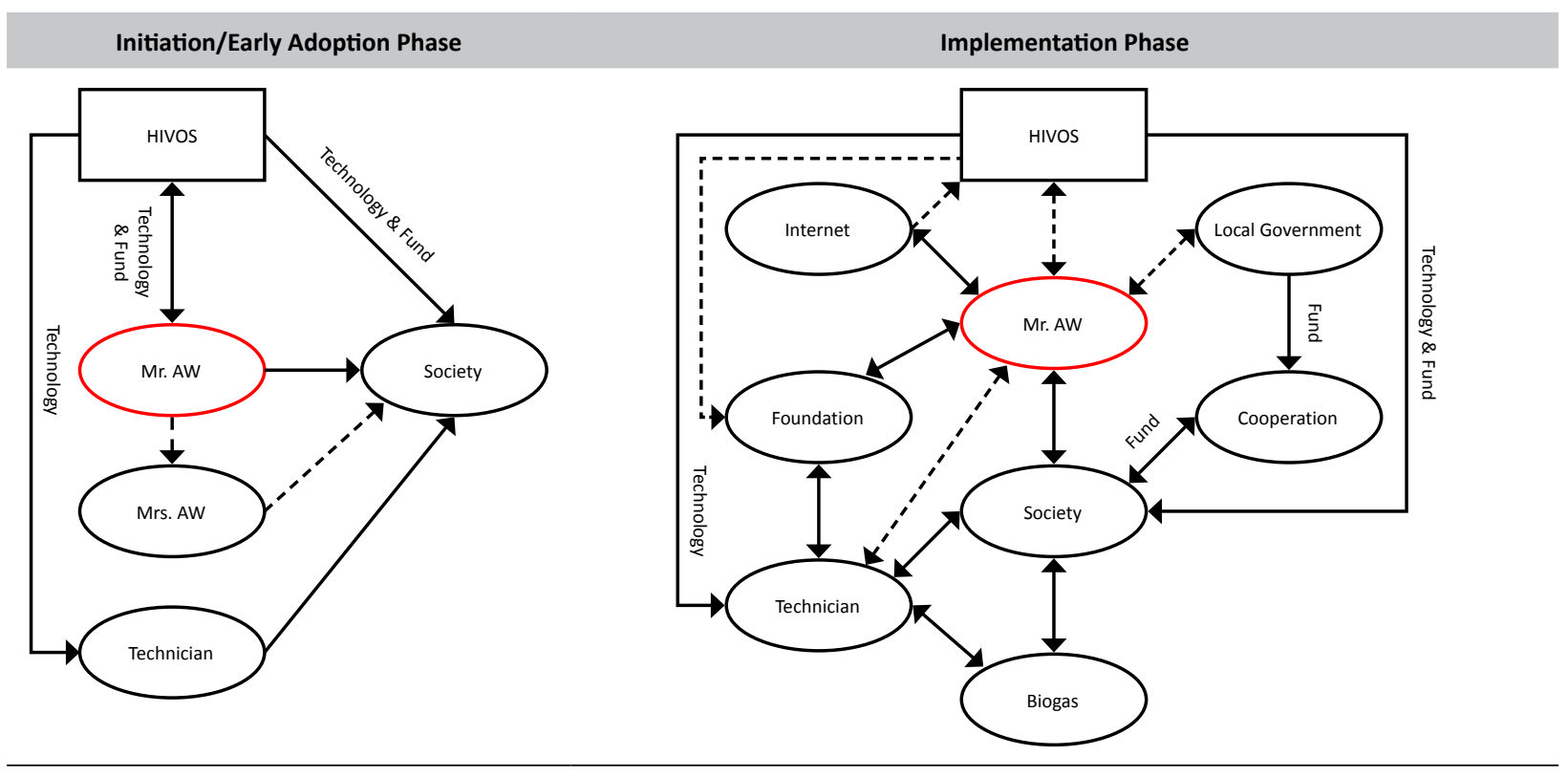

Figure 2. The Innovation Adoption Phase in Pandua Lantan Village, North Lombok 
can cause diseases such as diarrhea, then Mr. AW seek information through the internet and find HIVOS, which can provide clear information about the biogas. In early 2010, Mr. AW created biogas digester with the help of HIVOS. In addition to providing training to make digester, HIVOS also helped fund of IDR2 million. At this persuasion phase, Mr. AW sees many benefits of using biogas, such as not spending money to buy kerosene or gas, clean cowshed environment, not smelly, not a lot of flies, and get fertilizer for the vegetables from the rest of the biogas. Afterward, Mr. AW communicated to his neighbors and also to the villagers through village meetings, recitals, fathers' meetings, and informal meetings. The next stage, after listening to the explanation of Mr. AW and saw the biogas at Mr. AW's home, then a lot of people wanted to make the biogas. In addition, AW also unofficially communicated to the mothers.

From the explanation above, it can be concluded that the success of the local initiator in influencing people for adopting the biogas technology innovation is not affected by occupation, age, gender, just as in the Haurngombong Village, the one who socializes or communicates it is the village head who has the highest authority in the village and old, but the fact is he cannot affect the success of the biogas innovation adoption, while in Pandua Village, the one who socializes or communicates it is a young man who does not have any positions in the village and even he managed to persuade young people to adopt biogas. Actually, what is needed in influencing the community is the way to communicate the innovation to the public, without patronizing or forcing, the experience of using biogas, knowledge about biogas, also added examples of the use of biogas and its positive impact. In addition, the participation of the wife of AW from Pandua Village in communicating the use of biogas and its benefits to mothers, it seems there is a division of labor that is not artificial and happens naturally, in which Mr. AW communicates to the fathers and his wife to the mothers. This is affecting the successful adoption in Pandua Lantan Village. In 2010, the number of residents in Pandua village is 120 families and there are $56.67 \%$ or as many as 68 families already using the biogas, and in 2012 it amounted to $94.17 \%$ or only 3 families that are yet to using biogas. After Mr. AW succeeded in disseminating biogas in the region, Mr. AW also communicated and helped to make a digester in another village. Mr. AW, along with 17 people from Pandua village, already has a certificate from the HIVOS Centre since 2013 and has made the foundation for the preparation of the digester. In 2013, Mr. AW and his foundation got the job to build 300 digesters by Distamben of NTB and Hivos, and in 2014 built 2,000 pieces of digesters. For the sustainability of the biogas energy adoption in the area of dairy farms, needed a role of local governments, especially with funds the Ministry of ESDM called DAK and funds of the Ministry of Rural Area called Village Fund disbursed this year that could be used to expand the biogas innovation adoption in other villages.

\section{The Role of Actor}

The success in the innovation adoption is inseparable from the role of a person in making a change. The role of a person who is a local initiator or a local change agent in the successful adoption of innovation is as 1) a catalyst who has a role in convincing another person or group of people about the importance of change towards the better, 2) a solution giver or a solution provider that acts as a reminder to another person or group of people toward the ultimate goal of the changes being jointly implemented, 3) a process helper who contributes to help smoothen the process of change, especially solving the problems that arise and build relationships between the parties involved, and 4) a resources linker or resources liaison whose role is to connect people with the owner of the source of funds/tools needed and the duty to collaborate and raise funds.

\section{1) Haurngombong Village}

The local initiator role in the adoption of technology innovations in Figure 1 of the implementation part, that in the phase of Catalyst, $\mathrm{Mr}$. A as a village head is assisted by Mr. $\mathrm{K}$ and Mr. $\mathrm{G}$ and the younger generation to communicate and encourage people to use biogas in order to be more efficient because they do not spend money to buy kerosene, environmentally clean, healthy, and does not smell, reduce illnesses caused y flies, and certainly safer because it could not explode like the kerosene stove. In addition, the residual impurities (slurry) can be used as fertilizer for crops and can also be sold. After the village-owned enterprise established, it also helps in communicating the use of biogas.

As a solution giver or a solution provider, $\mathrm{Mr}$. A was the one firstly exemplifying the use of biogas or acted as the Early Adopter. Although initially rejected by the people, Mr. A kept giving an example and communicated the many benefits obtained by using biogas, especially after the scarcity of kerosene.

In the phase of a process helper, which is the scarcity and high price of kerosene, then people have a desire to use biogas. The village head (Mr. A), assisted by community leaders named Mr. G and Mr. $\mathrm{K}$, sent a letter to the Faculty of Animal Husbandry of Padjadjaran University (UNPAD), Bandung to ask for help in making biogas digesters as well as providing a training on how to use the biogas to the 
people and a training on how to make the digesters to the younger generation. Biogas users are not only breeders but also the non-breeders. Nonbreeders buy cattle manure from other farmers to fill their digesters. The village head also established a village-owned enterprise. This business is managed by three core employees and supported by 20 technicians who have been trained by UNPAD. The services of this business entity, among others, include the procurement and installation of biogas, the supply of spare parts, and savings and loans to help manufacturing the digesters and the payment can be paid in installments with 1 liter of milk per day.

The resources linkers phase, Mr. A as the village head, in addition to linking UNPAD for technological assistance and training, also raising funds for the manufacture of digesters, one of which from SEKAR. In 2008, the village head, helped by UNPAD, sent a letter to PLN to develop the biogas for the village electricity. PLN helped with 10 units of generators. In 2010, the Ministry of Energy and Mineral Resources (ESDM) helped with digesters and stoves, and HIVOS also helped with finance scheme for the manufacture of digesters with the aid of IDR2 million per digester.

\section{2) Pandua Lantan Village}

The role of MR. AW as the local initiator in the adoption of technological innovation, initially working alone from seeking information about biogas and HIVOS (Figure 2). In the Catalyst phase, Mr. AW was assisted by HIVOS and the local government to communicate and encourage people to use biogas. And Mrs. AW, as the village midwife, participated in communicating the use of biogas and its benefits to the mothers.

In the solution giver or solution provider phase, Mr. AW acts as the Early Adopter in the use of biogas. Once obtained a lot of benefits by using biogas, Mr. AW shared his experience in Korea and in his house in the use of biogas to the surrounding communities and even to the whole village. He also tells the leftover of biogas (slurry) that can be used to fertilize crops. In the process helper phase, $\mathrm{Mr}$. AW is assisted by HIVOS in communicating about biogas and providing training on how to use biogas properly and help to provide the manufacturing cost of the digester of IDR2 million. HIVOS is a Dutch nonprofit non-governmental organization with its blue program to help the poor and the marginalized, to help provide financial resources in the construction of house biogas (digester) (Hermawati, 2011). In addition, HIVOS also gives training to some villagers as technicians in the manufacture of digesters, provides certification to technicians, and provide consultation if there is a problem. In addition to asking HIVOS for help, in resource linker or resource liaison phase, Mr. AW is also assisted by the local government in the form of funding for the making of digesters worth of IDR3 million which is used through cooperatives.

From the above description, mentioned that the role of a local initiator as the actor who has an important role in changing society towards the better, in terms of economy, environment, and health. In Haurngombong Village, the success of the adoption of biogas depends on a) convincing the people to adopt the biogas must be assisted by community leaders although $\mathrm{Mr}$. $\mathrm{A}$, as the village head, has the highest authority in the village, b) Mr. A must be the Early Adopter to convince people. It indeed happened that people would not want to adopt before seeing the innovation, c) the scarcity and high price of kerosene, d) in the construction of biogas digesters, it has been assisted by faculty of Animal Husbandry of Padjadjaran University in 2008, e) in the financing is assisted by SEKAR, Ministry of ESDM, and HIVOS, and f) this village also received an assistance from PLN (generator) to build electricity in the village. While the successful adoption of biogas in Pandua Village, depends on, a) Mr. AW assisted by Mrs. AW in communicating the biogas, and HIVOS to explain about the making of the digester, a digester technician training, b) Mr. AW becomes an Early Adopter to reassure and give an example to the community. As in the previous village, the financing is assisted by SEKAR, Ministry of ESDM, and HIVOS, and f) this village also received an assistance from PLN (generator) to build electricity in the village. Meanwhile, the successful adoption of biogas in Pandua Village depends on, a) Mr. AW assisted by Mrs. AW in communicating the biogas and HIVOS to explain about the manufacture of the digester, digester technician training, b) Mr. AW becomes an Early Adopter to reassure and give an example to the community. Just as in Haurngombong Village that people should first see then adopt, c) in the financing is assisted by HIVOS in the amount of IDR2 million and the Government of IDR1,200,000.00 in which the distribution is through 'Sentul Jaya' cooperatives, so that people only pay IDR835,000.00 in the manufacture of the digester. If people do not have money, they can borrow to cooperatives and the payment can be paid in installments of IDR55,000.00/month.

\section{The Success of a Local Initiator as the Agent of Change}

According to Roger, there are eight factors that affect a local initiator in influencing the society (Rogers E.M, 1962; Ishelina and Hartiningsih, 2014), as in Table 1. In the table, can be seen that in Haurngombong Village and Pandua Village, the main role performed by the local initiator as the agent of change is the person who first sparked the 
idea of using biogas. The idea of using biogas can be from a) another person, such as in Haurngombong Village, it is a lecturer from ITB who was conducting a research in the village, and b) its own initiative which is seeking information from the Internet as is done in Pandua village. To achieve the goal of change or innovation in the region, the local initiator must, among other things:

1. Becomes an Early Adopter or Role Model in the use of biogas.

2. Be responsible for disseminating or diffusing the biogas innovation. In the socialization, he may be assisted by religious leaders and village youths (Haurngombong Village), as well as by the wives (Pandua village) although not directly, and non-governmental organizations (HIVOS). The innovation must be done in accordance with the needs of the community and have a positive impact, such as a clean environment, no flies, reduce spending, reduce the disease (diarrhea, ARI/respiratory problem), reducing time spent on cooking. In addition, it is also how the local initiator communicates such innovations. How this communication becomes an important factor in the successful adoption of innovation, which must be done properly and politely without being patronizing, easy to understand/clear, with knowledge about biogas, can be assured, could explain, willing to work hard in order to get the empathy of the public. In disseminating the biogas innovation, the local initiator communicates it through village meetings, lectures, and informally, such as chatting in front of the house, on the way after going to the mosques, etc. In disseminating the biogas innovation, the local initiator is not influenced by position and age, or even wealth, such as in Pandua Village, in which a local initiator is a young man, does not have any important position but even more successful than in Haurngombong Village, in which a local initiator is the village head and is old. The important factor in the successful adoption is the persistence of the local initiator in disseminating the biogas innovation without despair, with the courage to take risks, such as in Haurngombong Village, who was initially rejected by the people and also influenced by a clear information and the experience in using biogas.

3. Be responsible for the manufacture of the digesters. In Haurngombong Village, the manufacture of the digesters is done by the people who are trained and guided by the Faculty of Animal Husbandry of Padjadjaran University, while in Pandua Village, the people making the digesters are technicians who have attended a training from HIVOS and have received a certificate from HIVOS.

4. Find assistance in funding the manufacture of the digester. The funding in the manufacture of the digesters in Haurngombong Villages is from self-financing or loan money from business entities formed by the village Head, grants from private institutions (ASEKAR, HIVOS), as well as central and local governments. While in Pandua Village, with the help of HIVOS in the amount of IDR2 million and the rest is from the self-financing funds and loans from the cooperative, and the funding of local government.

5. Community empowerment. A local initiator should be able to empower the people, as was done in Haurngombong Village, which formed a business entity as a conduit of funds from the central/local government and private funds for the manufacture of the digester and the children education, the sale of organic fertilizer from the leftover of the biogas (slurry), as well as providing a training for the manufacture of the digesters and administration. Moreover, in Haurngombong Village, the mothers are given a training on how to make organic fertilizers from the slurry. While in Pandua Village, the local initiator builds a foundation that is used to channel funds from local governments and HIVOS for the manufacture of the digester, digester making training, and do a cooperation on the manufacture of the digesters for Pandua region or in other regions from HIVOS and local governments for technicians who have been certified.

Social changes that occur in the people of Haurngombong Village and Pandua Village are, among others:

1. Change of mindset, among other things, the parents can send their children to school, because of the expenditure cutting, increased revenue, and can borrow to business agency/ foundation.

2. Change of habits, including public awareness, especially the mothers who are willing to make biogas with cow dung, the teens who are willing to work in enterprises and make fertilizer (Haurngombong Village) and become the technicians for the manufacture of digesters (Pandua Village), children are studying diligently, and the fathers are gardening diligently using organic fertilizers.

3. Change in economic conditions, among others, by using biogas, people can save money because they do not buy kerosene or wood. In addition, people earn extra money from the sale of slurry (biogas waste) to be used as organic fertilizer (in Haurngombong Village), 
Table 1.

Factors Affecting Local Initiators

\begin{tabular}{|c|c|c|c|}
\hline No & Local Initiators Success & Haurngombong Village, West Java & Pandua Lantan Village, NTB \\
\hline 1 & $\begin{array}{c}\text { The Effort of the Change } \\
\text { Agent Himself }\end{array}$ & $\begin{array}{l}\text { - Mr. A as a local resident and at that time } \\
\text { became a Village Head } \\
\text { - With his own initiative, Mr. A asked the favor } \\
\text { of ITB to make a digester from plastics. } \\
\text { - Biogas is used for households needs. } \\
\text { - Hold a dissemination on biogas assisted by the } \\
\text { community leaders (Mr. K and Mr. G). }\end{array}$ & $\begin{array}{l}\text { - Mr. AW is the local resident that turned into } \\
\text { an Early Adopter. } \\
\text { - With his own initiative seeking information } \\
\text { about biogas } \\
\text { - Mr. AW disseminated to surrounding } \\
\text { communities through RT/RW meetings RW, } \\
\text { RT, recitals, meetings with the fathers and } \\
\text { informal chat in front of his house or on the } \\
\text { way or interacting via the Internet. }\end{array}$ \\
\hline 2 & Client Orientation & $\begin{array}{l}\text { - Mr. A as the example for the use of biogas and } \\
\text { becomes the agent of change in the use of } \\
\text { - Responsible for disseminating the biogas } \\
\text { assisted by the community leaders. } \\
\text { - Has a cooperation with Animal Husbandry } \\
\text { Faculty of UNPAD by providing biogas } \\
\text { assistance and guidance for the community, as } \\
\text { well as proving a training of the management } \\
\text { and the proper use of the biogas. And just } \\
\text { in } 2010 \text {, the Ministry of ESDM joined to help } \\
\text { with the provision of digesters, stoves, and } \\
\text { HIVOS with financing aid. }\end{array}$ & $\begin{array}{l}\text { - Mr. AW as the Role Model in the use of biogas } \\
\text { and the agent of change. } \\
\text { - Responsible for disseminating the biogas. } \\
\text { took HIVOS to help people in the manufacture } \\
\text { of the digester, how to use it, and the funding. } \\
\text { HIVOS gives training to the community to } \\
\text { make the digester and in } 2013 \text { there were } 18 \\
\text { certified biogas technicians from HIVOS. }\end{array}$ \\
\hline 3 & $\begin{array}{l}\text { The Suitability of Innovation } \\
\text { with Client Needs }\end{array}$ & $\begin{array}{l}\text { - Mr. A as the agent of change has been } \\
\text { successful in adopting the biogas innovation } \\
\text { into society, in accordance with the needs of } \\
\text { the communities using cow waste. } \\
\text { - The success was marked by many people using } \\
\text { the biogas. } \\
\text { - The biogas program has greatly helped the } \\
\text { community of cattle breeders who used to use } \\
\text { kerosene. } \\
\text { - With biogas, cooking can be quicker, the house } \\
\text { is clean, reduce the occurrence of disease, } \\
\text { clean environment that is free from of flies } \\
\text { and smells. }\end{array}$ & $\begin{array}{l}\text { - Mr. AW as the agent of change has been } \\
\text { successful in adopting the biogas innovation } \\
\text { into society, in accordance with the needs of } \\
\text { the communities using cow waste. } \\
\text { - The success was marked by many people using } \\
\text { biogas. } \\
\text { - Some local communities have become } \\
\text { certified technicians from HIVOS. } \\
\text { - The biogas program has helped the } \\
\text { community in the provision of free fuel, which } \\
\text { used to use wood. With the biogas, they } \\
\text { can cook faster, clean the house, reduce the } \\
\text { occurrence of disease because of the smoke } \\
\text { from firewood, and clean environment from } \\
\text { flies and smells. }\end{array}$ \\
\hline 4 & $\begin{array}{l}\text { Empathy from the Agent of } \\
\text { Change }\end{array}$ & $\begin{array}{l}\text { After the scarcity and the high price of kerosene, } \\
\text { Mr. A assisted with the community leaders and } \\
\text { village youths communicated the kerosene } \\
\text { replacement solution by using biogas and seeing } \\
\text { the positive impact of biogas that was used Mr. } \\
\text { A, then the community to empathize with the } \\
\text { idea that the adoption of biogas was successful. }\end{array}$ & $\begin{array}{l}\text { With the persistence of MR. AW who tried to } \\
\text { change the environment and communicated } \\
\text { the positive impact with biogas, made } \\
\text { the community empathized with the idea } \\
\text { that it could influence the effectiveness of } \\
\text { communication so as to accelerate the adoption } \\
\text { of biogas. }\end{array}$ \\
\hline 5 & Interaction with Client & $\begin{array}{l}\text { Mr. } A \text { is a local resident and a village head and } \\
\text { assisted by the community leaders and village } \\
\text { youths so that the interaction can work well. }\end{array}$ & $\begin{array}{l}\text { Mr. AW, who comes from the local region, knows } \\
\text { the culture of Pandua village, is known and also } \\
\text { knows how to communicate with the community } \\
\text { so that the interaction with the community can } \\
\text { work well. }\end{array}$ \\
\hline 6 & $\begin{array}{l}\text { The Credibility of the Agent } \\
\text { of Change }\end{array}$ & $\begin{array}{l}\text { - Mr. A as the village head has the authority and } \\
\text { is respected in his village } \\
\text { - Mr. A gives an example of using biogas for } \\
\text { household } \\
\text { - find the assistance of fund for the } \\
\text { manufacture of biogas from ASEKAR, Ministry } \\
\text { of ESDM, and HIVOS } \\
\text { - find the assistance for generator set from PLN } \\
\text { to light up the village make a business entity } \\
\text { for borrowing money to make biogas and bio- } \\
\text { slurry fertilizers. }\end{array}$ & $\begin{array}{l}\text { - The relation of Mr. AW with the community is } \\
\text { very familiar, they often share the story while } \\
\text { he was a migrant worker so that they know } \\
\text { that Mr. AW had known and been using the } \\
\text { biogas. } \\
\text { - Mr. AW gives an example of using the biogas } \\
\text { to meet the household needs } \\
\text { - Mr. AW made the foundation and become a } \\
\text { partner with HIVOS for biogas production. }\end{array}$ \\
\hline
\end{tabular}

The Local Initiator Role in the Adoption of Biogas Energy Innovation for Household Needs in Rural Areas 


\begin{tabular}{|c|c|c|c|}
\hline No & Local Initiators Success & Haurngombong Village, West Java & Pandua Lantan Village, NTB \\
\hline 7 & $\begin{array}{l}\text { In Line with the Opinion } \\
\text { Leader }\end{array}$ & $\begin{array}{l}\text { Mr. A was initially ignored in suggesting the } \\
\text { use of biogas, although Mr. A acted as the } \\
\text { village head. However, after the community } \\
\text { experienced the scarcity and the increased } \\
\text { price of kerosene as well as with the assistance } \\
\text { of the community leaders and village youths } \\
\text { in campaigning the use of biogas and its } \\
\text { advantages and see the use of biogas in Mr. A's } \\
\text { house, then the community finally welcomed } \\
\text { the adoption of biogas. }\end{array}$ & $\begin{array}{l}\text { With his experience of using biogas in Korea } \\
\text { as well as in his household, Mr. AW can } \\
\text { communicate a positive impact of using biogas, } \\
\text { which can affect people for using biogas and it } \\
\text { coincided with the entrance of HIVOS program } \\
\text { to help the people in the financing and the } \\
\text { making of biogas. The program was well } \\
\text { received by the community. }\end{array}$ \\
\hline 8 & $\begin{array}{c}\text { The Client Evaluation } \\
\text { Capability }\end{array}$ & $\begin{array}{l}\text { - At first, Mr. A was difficult in making changes } \\
\text { in his communities, although Mr. A has started } \\
\text { using biogas for households. } \\
\text { - After the problems of the scarcity and the } \\
\text { rising price of kerosene, and also assisted by } \\
\text { the community leaders and village youths to } \\
\text { campaign the use of biogas, and also seeing } \\
\text { that those problems were not experienced } \\
\text { by Mr. A's family which have been using the } \\
\text { biogas, then eventually the community was } \\
\text { interested in using biogas. } \\
\text { - In order to make the people not depending on } \\
\text { Mr. A, whose function is the agent of change, } \\
\text { then the community was invited to participate } \\
\text { in financing the manufacture of biogas } \\
\text { digester, its maintenance, and its management } \\
\text { in order to feel ownership by the Faculty of } \\
\text { Animal Husbandry of Padjadjaran University } \\
\text { and HIVOS. }\end{array}$ & $\begin{array}{l}\text { - To make a change, Mr. AW started with his } \\
\text { family in using biogas, after seeing the results } \\
\text { and its positive impact, Mr. AW, and Mrs. AW } \\
\text { communicated and introduced it to the local } \\
\text { community. } \\
\text { - The community was interested to also use } \\
\text { biogas so that the suggestion to make a } \\
\text { change in Lantan did not take that long, it was } \\
\text { because Mr. AW and Mrs. AW had the right } \\
\text { strategy since Mr. AW was the local resident } \\
\text { and understood how to approach the local } \\
\text { community. } \\
\text { - In order for the community to not depend } \\
\text { on the agent of change, with the assistance } \\
\text { from HIVOS, the community helped to make } \\
\text { and finance the manufacture of the biogas } \\
\text { digesters so that community has the sense of } \\
\text { ownership and the maintenance as well as the } \\
\text { management and does not depend on Mr. AW, } \\
\text { whose role is the agent of change. }\end{array}$ \\
\hline
\end{tabular}

being the technician for the manufacture of digesters and the improvement of vegetable crops with the use of organic fertilizers.

The benefits received by the public by using biogas are (1) the environment is clean and free from flies, (2) the community is free from diarrhea and ARI/respiratory problem (from the cooking wood smoke), (3) the kitchen is clean because biogas has no smoke, no smell, the stove cannot explode, and does not blacken the kitchen tools, (4) more efficient because it does not spend money to buy kerosene or firewood, (5) youths get jobs for making fertilizer, managing business/foundation, being the technicians for the manufacture of digesters, (6) the productivity of crops increases, and (7) the increase in revenues from the sale of crops and the sale of slurry.

The barrier of change in the use of biogas, at first only occurred in Haurngombong Village, which was the rejection of the public since they had to spend money to build a digester and kerosene was still easily obtained at a low price, and in there was no barrier in Pandua Village.

\section{Conclusion}

The development of biogas is one form of alternative solution to the scarcity and high cost of kerosene that is commonly used in households which has been supported by Presidential Regulation No 5 of 2006 and the Regulation of the Minister of Energy and Mineral Resources No 10 of 2015, and the Regulation of the Minister of Village No 5 of 2015. In addition, the development of biogas can also be a solution to the management of animal waste that can be put to productive use and can help address the environmental issues and the health of rural communities. In order for rural communities to adopt biogas, very needed a help of a local initiator as the agent of change. The initiator is a Role Model or an Early Adopter before the people to adopt such innovation. In addition, the local initiator is the one that can socialize and communicate about the biogas innovation to rural communities. The local initiator needed does not depend on the age, occupation, or wealth. The local initiator who can communicate well and polite without being patronizing, easy to understand/clear, has knowledge about biogas, can be assuring, can be construing, works hard in order to get the empathy of the public so that adoption innovation can succeed, and wants to help to find the funds for the digester construction.

By using biogas, many rural communities get the benefits, which among other is more efficient because they do not spend money to buy kerosene or gas, it is safer because biogas stoves cannot explode, the home environment becomes clean, not 
a lot of flies, and can reduce diarrheal disease.

For the sustainability of the biogas energy adoption, in addition to continue to be communicated to the rural community, especially cattle ranchers, either through gatherings, recitals, neighborhood, or through radio, the role of local government is also very necessary, especially the digester development aid, especially since 2013 with the existence of the DAK fund of the Ministry of energy and Mineral Resources and the existence of village fund disbursed this year, one of which is aimed at biogas and renewable energy development.

While the most dominant factors of the eight factors that affect the initiator role in the success of diffusing the biogas innovation, is a factor of the effort of the agent of change itself that dare to be $a b$ Early Adopters and a Role Models as well as dare to be responsible for the diffusion of these innovations, by a good communication and a clear knowledge of such innovations. If this factor is weak, then the diffusion of innovation will not work.

\section{ACKNOWLEDGEMENT}

This article is part of a research report of PAPPIPTEK LIPI in 2011 to 2014. The author would like to thank PAPPIPTEK LIPI which has helped to allocate the DOPA fund for this study. Gratitude is also expressed to the colleagues in the research team who are allowed to write in this section.

\section{REFERENCES}

Agustino, L. (2008). Dasar-dasar Kebijakan Publik (1st ed.). Bandung: Alfabeta.

Harsiwi, T. (2016). Pemahaman Manajemen Perubahan dalam Perspektif Agen Perubahan Pendidikan Tinggi. tulisanterkini.com. Retrieved 18 May 2016, from http://tulisanterkini. com/artikel/tip-dan-trik/3219-pemahamanmanajemen-perubahan-dalam-perspektifagen-perubahan-pendidikan-tinggi.html

Hartiningsih, Wati H., Ikbal M., dan Ishelina R. 2013. Peran Jejaring dan Aktor dalam Mempertahankan Kesinambungan Energi di Perdesaan. Laporan Hasil Penelitian Pappiptek-LIPI. Katalog Perpustakaan Pappiptek-LIPI No. 333.7/Per/H, Seri Laporan Penelitian No. 2014-01-01-04.

Hartiningsih,. (2015). Jejaring dalam Difusi Inovasi Tungku Sehat Hemat Energi (TSHE) Kasus: Kulon Progo D.I. Yogyakarta. Jurnal Pekommas, 18(2), 73-82. Retrieved from https://jurnal. kominfo.go.id/index.php/pekommas/issue/ view/78

Haryati, T. (2006). Biogas: Limbah Peternakan yang Menjadi Sumber Energi Alternatif. Wartazoa, 16(3), 160-169. Retrieved from http://kalteng. litbang.pertanian.go.id/ind/pdf/all-pdf/ peternakan/fullteks/wartazoa/wazo163-5.pdf Hermawati, Wati, Ikbal M., Hartiningsih, Ishelina, Sigit S., Sayim D., Purnama (2011). Pola Pembiayaan Litbang dan Implementasi Energi Baru-Terbarukan di Indonesia, Kasus: PLTMH dan Biogas. Laporan Penelitian PAPPIPTEKLIPI.

Kaho, J. (1996). Mekanisme Pengontrolan dalam Hubungan Pemerintah Pusat dan Daerah (1st ed., p. 20). Jakarta: Bina Aksara.

Kementerian Desa, Pembangunan Daerah Tertinggal, dan Transmigrasi Republik Indonesia,. (2015). Peraturan Menteri Desa, Pembangunan Daerah Tertinggal, dan Transmigrasi Republik Indonesia No 5 Tahun 2015 tentang Penetapan Prioritas Penggunaan Dana Desa Tahun 2015. Jakarta: Kementerian Desa, Pembangunan Daerah Tertinggal, dan Transmigrasi Republik Indonesia.

Kementerian Energi dan Sumber Daya Mineral Republik Indonesia,. (2013). Peraturan Menteri Energi dan Sumber Daya Mineral Republik Indonesia No 3 Tahun 2013 tentang Petunjuk Teknis Penggunaan Dana Alokasi Khusus Bidang Energi Perdesaan. Jakarta: Kementerian Energi dan Sumber Daya Mineral Republik Indonesia.

Kementerian Energi dan Sumber Daya Mineral Republik Indonesia,. (2015). Peraturan Menteri Energi dan Sumber Daya Mineral Republik Indonesia No 10 Tahun 2015 tentang Petunjuk Teknis Penggunaan Dana Alokasi Khusus Bidang Energi Perdesaan Tahun Anggaran 2015. Jakarta: Kementerian Energi dan Sumber Daya Mineral Republik Indonesia.

Martaleo, M., Nawangpalupi, C., Pratiwi, L., \& Herawati, Y. (2014). Evaluasi Peraturan Pembelian Energi Terbarukan pada Desa Peternak Sapi untuk Meningkatkan Keamanan Energi di Ciater, Subang. Research Report Engineering Science, 2. Retrieved from http:// journal.unpar.ac.id/index.php/rekayasa / article/view/1096

Moleong, L. (2002). Metodologi Penelitian Kualitatif (1st ed.). Bandung: Remaja Rosdakarya.

Muflikhati, I., Yuliati, L., \& Maulanasari, R. (2011). Pengetahuan Istri dan Pengaruhnya terhadap Pengambilan Keputusan Penggunaan Biogas. Jurnal Ilmu Keluarga Dan Konsumen, 4(1), 9197.

Musanif, J. (2009). Biogas (1st ed.). Departemen Pertanian.

Peshin, R., Vasanthakumar, J., \& Kalra, R. (2009). Diffusion of Innovation Theory and Integrated Pest Management. In R. Peshin \& A. Dhawan, Integrated Pest Management - Volume 2: Dissemination and Impact (1st ed.). Dordrecht: Springer. 
Rahmadhani, N. (2009). Tenaga Lapangan sebagai Agen Perubahan dan Pemberdayaan Perempuan (Studi Kasus tentang Peranan Tenaga Lapangan sebagai Agen Perubahan terhadap Pemberdayaan Perempuan pada Yayasan untuk Perempuan Perkotaan Medan) (Undergraduate Thesis). Universitas Sumatera Utara.

Rogers, E. (2003). Diffusion of Innovations (5th ed.). New York: The Free Press.

Rogers, E. \& Shoemaker, F. (1971). Communication of Innovations: A Cross-Cultural Approach (1st ed.). New York: Free Press.

Rosaira, I. \& Hartiningsih,. (2014). Peran Agen Pengubah dalam Keberhasilan Difusi Inovasi Biogas di Desa Pandua Lombok Utara. In Prosiding Forum Tahunan Pengembangan Ilmu Pengetahuan Teknologi dan Inovasi (IPTEKIN) IV. PAPPIPTEK-LIPI.

Rosaira, I., Hermawati, W., Maulana, I., \& Hartiningsih,. (2014). Strategi Mempertahankan Keberlanjutan Adopsi Energi Terbarukan di
Tingkat Masyarakat Perdesaan: Studi Kasus PLTMH dan TSHE. Jakarta: PAPPIPTEK-LIPI.

Simatupang, T. (2016). Metode Penelitian Kualitatif. In Lokakarya Metode Penelitian Manajemen. PAPPIPTEK-LIPI.

Soekartawi,. (1998). Prinsip Dasar Ekonomi Pertanian (1st ed.). Depok: Rajagrafindo Persada.

Sugiyono,. (2014). Metode Penelitian Kombinasi (Mixed Methods) (1st ed.). Bandung: Alfabeta.

Sukmawati, A. (2013). Agen Perubahan dan Peranannya terhadap Kondisi Sosial Masyarakat di Desa Mlatiharjo Kecamatan Gajah Kabupaten Demak. Journal OfEducational Social Studies, 2(1), 22-28. Retrieved from http://journal.unnes.ac.id/sju/index.php/ jess/article/view/1297

Waluyo, E. \& Nurlia, A. (2013). Agen Perubahan dalam Pembangunan Hutan Rakyat: Belajar dari Pengembangan Kayu Bawang di Wilayah Propinsi Bengkulu. 